\title{
PENERAPAN MODEL PEMBELAJARAN PROBLEM BASED LEARNING UNTUK MENINGKATKAN KEAKTIFAN DAN HASIL BELAJAR PESERTA DIDIK
}

\author{
Sukirman \& Moch Solikin \\ Fakultas Teknik, Universitas Negeri Yogyakarta \\ Email: sukirmansadeg@gmail.com
}

\begin{abstract}
This study implemented the Problem Based Learning learning model to increase the students' activeness and learning outcomes in the conventional fuel system competency in class XI TKRA SMK Nasional Berbah. A Classroom Action Research (PTK) with Kurt Lewin's model was conducted, and the data were collected using observation, tests, and documentation. The indicator of the success of this study is if more than $75 \%$ of students are active and $75 \%$ of students reach the minimum score criteria (75). The participants of this study were 32 students of class XI. The results showed that the application of PBL able to increase the students' activeness and learning outcomes on the competence to understand the conventional gasoline fuel system. This can be seen from: (1) an increase in positive activities (activities that support the implementation of the teaching and learning process) and a decrease in negative activities (activities that interfere with the implementation of the teaching and learning process) in each cycle. Positive activity in cycle I was $51 \%$ and cycle II was 76\%; (2) there is an increase in the class average and students' learning completeness. The class average in cycle I was 71 and cycle II was 78. Meanwhile, students' learning completeness in cycle I was $43.75 \%$, cycle II was $84.37 \%$.
\end{abstract}

Keywords: Problem Based Learning, SMK Nasional Berbah

\begin{abstract}
Abstrak
Penerapan model pembelajaran Problem Based Learning ini dilakukan untuk meningkatkan keaktifan dan hasil belajar peserta didik pada kompetensi sistem bahan bakar konvensional kelas XI TKRA SMK Nasional Berbah. Penelitian Tindakan Kelas (PTK) dengan model Kurt Lewin ini menggunakan observasi, tes hasil belajar, dan dokumentasi sebagai data penelitian. Indikator keberhasilan penelitian ini jika lebih dari $75 \%$ peserta didik aktif dan $75 \%$ peserta didik mencapai KKM (75). Subjek penelitian ini adalah peserta didik kelas XI sebanyak 32 siswa. Hasil penelitian menunjukkan penerapan PBL dapat meningkatkan keaktifan dan hasil belajar peserta didik pada kompetensi memahami sistem bahan bakar bensin konvensional. Hal tersebut dapat dilihat dari: (1) adanya peningkatan aktivitas positif (aktivitas yang mendukung pelaksanaan proses belajar mengajar) dan penurunan aktivitas negatif (aktivitas yang mengganggu pelaksanaan proses belajar mengajar) pada tiap siklus. Aktivitas positif pada siklus I sebesar 51\% dan siklus II sebesar 76\%; (2) adanya peningkatan rata-rata kelas dan ketuntasan belajar peserta didik. Rata-rata kelas pada siklus I sebesar 71 dan siklus II sebesar 78. Sedangkan ketuntasan belajar peserta didik pada siklus I sebesar 43,75\%, siklus II sebesar $84,37 \%$.
\end{abstract}

Kata kunci: Problem Based Learning, SMK Nasional Berbah

\section{PENDAHULUAN}

Pendidikan merupakan salah satu kebutuhan bagi setiap manusia. Dengan adanya pendidikan diharapkan mampu untuk meningkatkan kemampuan dan kualitas SDM di Indonesia dalam menghadapi era pasar bebas. Dalam peningkatan kualitas pendidikan ini tidak 
dapat dilepaskan dari aspek pembelajaran. Hal ini sesuai dengan tujuan dari pendidikan yang telah disebutkan dalam Undang-Undang No.20 tahun 2003, tentang Sistem Pendidikan Nasional yang menjelaskan bahwa Pendidikan Nasional berfungsi mengembangkan kemampuan dan membentuk watak serta peradaban bangsa, bertujuan untuk berkembangnya potensi peserta didik agar menjadi manusia yang beriman dan bertaqwa kepada Tuhan Yang Maha Esa, berakhlak mulia, sehat, berilmu, cakap, kreatif, mandiri, dan menjadi warga negara yang demokratis serta bertanggung jawab. Disini sudah jelas bahwa untuk meningkatkan SDM yang berkualitas baik fisik maupun mental yang baik dibutuhkan pembangunan bidang pendidikan yang baik pula. Peningkatan kualitas pendidikan tersebut dapat diwujudkan dalam pembelajaran yang diarahkan untuk membantu peserta didik dalam mengusai kemampuan yang dipelajari guna mencapai tujuan yang diharapkan.

Pendidikan kejuruan merupakan suatu pendidikan yang mempersiapkan peserta didik untuk dapat menguasai keahlian tertentu agar menjadi tenaga kerja yang profesional. Hal ini didasarkan pada kebutuhan tenaga kerja di masa mendatang yang membutuhkan tenaga kerja yang berkualitas. Sekolah Menengah Kejuruan (SMK) adalah jenjang pendidikan menengah yang berada satu tingkat di atas SMP/MTs, secara umum di jenjang SMK bertujuan untuk membekali peserta didiknya dengan keahlian tertentu sesuai dengan yang diminati. Hal ini sesuai dengan tujuan SMK yang dijelaskan dalam pasal 3 Undang-Undang Sistem Pendidikan Nasional tahun 2003 yang menjelaskan bahwa "Pendidikan Kejuruan adalah pendidikan menengah yang mempersiapkan peserta didik terutama untuk bekerja dalam bidang tertentu". Berdasarkan tujuan tersebut maka untuk menyiapkan tenaga kerja yang berkualitas dibutuhkan kemampuan yang memadai untuk mencapai hasil yang diharapkan.

Berdasarkan observasi yang telah dilakukan di SMK Nasional Berbah ketika melaksanakan Program Lapangan Terbimbing (PLT) pada 15 September 2017 - 15 November 2017, kelas XI Program Keahlian Teknik Kendaraan Ringan (TKR) dibagi menjadi tiga kelas yaitu kelas TKRA, TKRB dan TKRC. Kelas XI TKRA terdiri dari 32 peserta didik, kelas XI TKRB terdiri dari 33 peserta didik dan kelas XI TKRC terdiri dari 30 peserta didik. Dari masing-masing peserta didik mempunyai tingkat pemahaman yang berbeda-beda. Sebagian guru dalam pembelajaran masih menggunakan metode pembelajaran konvensional (ceramah) dan menulis pada papan tulis yang tidak melibatkan peserta didik secara aktif. Pembelajaran dengan metode ceramah dilaksanakan dengan cara guru menyampaikan materi di depan kelas, sedangkan peserta didik mendengarkan dan mencatat, sehingga pada waktu peserta didik diberikan kesempatan untuk bertanya sebagian besar peserta didik tidak mengambil kesempatan tersebut. Hal ini disebabkan karena peserta didik tidak paham terkait materi yang disampaikan oleh guru. Salah satunya adalah pada mata pelajaran Pemeliharaan Mesin Kendaraan Ringan (PMKR) 
kompetensi sistem bahan bakar bensin yang masih menggunakan metode pembelajaran ceramah. Metode pembelajaran konvensional (ceramah) merupakan model pembelajaran yang berpusat pada guru (teacher centered learning).

Kurikulum yang digunakan sekarang di SMK Nasional Berbah adalah Kurikulum 2013 yang pada dasarnya pembelajaran dalam kelas menuntut keaktifan dan partisipasi siswa lebih dibanding kurikulum sebelumnya yaitu KTSP. Dalam hal ini di istilahkan dengan Student centered learning atau siswa yang menjadi pusat pembelajaran dalam kelas, jadi guru hanya menjadi fasilitator dalam pembelajaran. Namun kenyataanya masih banyak guru yang dalam pembelajaran masih konvensional dengan metode ceramah (teacher centered learning). Hal ini berdasarkan pada observasi pembelajaran pada tanggal 25 Oktober 2018 diketahui bahwa guru mengajar selama 120 menit. 90 menit guru menerangkan materi dan peserta didik hanya mendengar dan mencatat, sedangkan 30 menit guru memberikan tugas berupa soal untuk dikerjalan peserta didik.

Pada saat proses pembelajaran teori, peserta didik kurang semangat dan kurang aktif dalam mengikuti pembelajaran. Hal tersebut disebabkan karena materi yang disampaikan oleh guru kurang dapat diterima secara maksimal oleh peserta didik, sehingga akan berdampak pada hasil belajar peserta didik. Hasil belajar peserta didik di SMK Nasional Berbah masih tergolong rendah, hal ini terlihat dari banyaknya peserta didik yang hasil belajarnya kurang dari Kriteria Kelulusan Minimal (KKM) yaitu 75 pada mata pelajaran Pemeliharaan Mesin Kendaraan Ringan.

Berdasarkan hasil pretes yang dilakukan pada hari kamis tanggal 1 November 2018 kelas XI TKRA diketahui bahwa dari 32 peserta didik hanya 2 peserta didik atau sebesar $6,25 \%$ yang sudah mencapai KKM, dan 30 peserta didik atau sebesar 93,75\% masih belum mencapai KKM. Sedangkan hasil nilai UAS semester gasal tahun 2018 kelas XI TKRA diketahui bahwa dari 32 peserta didik belum ada yang mencapai KKM atau kalau di presentasikan sebesar $0 \%$.

Kurang tepatnya model pembelajaran yang diterapkan diduga menyebabkan lulusan SMK di dunia Industri kurang diterima. Berdasarkan data Badan Pusat Statistik (BPS) per Agustus 2018, tingkat pengangguran terbuka tertinggi pada jenjang pendidikan SMK sebesar 11,24\%. Kondisi tersebut dapat dijelaskan bahwa lulusan SMK tidak mampu bergabung ke dalam dunia industri ataupun dunia usaha, sehingga banyak yang menjadi pengangguran. Salah satu penyebab ketidakmampuan lulusan SMK untuk bergabung dalam dunia industri atau dunia usaha adalah sesorang lulusan SMK tidak dapat mengatasi masalah yang dihadapinya dikarenakan ia belum terbiasa menghadapi permasalahan. Untuk menghasilkan lulusan yang mampu menghadapi masalah, maka guru dapat menggunakan model pembelajaran yang sesuai. Salah satu model pembelajaran yang dapat digunakan adalah model pembelajaran problem 
based learning. Hal ini dikarenakan dalam penggunaan model pembelajaran problem based learning menggunakan permasalahan sebagai bahan diskusi pembelajaran. Permasalahan tersebut akan dipecahkan oleh peserta didik. Dengan adanya pembelajaran ini, diharapkan peserta didik akan terbiasa menghadapi masalah dan mampu memecahkannya.

Proses pembelajaran yang dilakukan pada kompetensi sistem bahan bakar, peserta didik cenderung lebih senang diberikan tugas sebagai pengganti pembelajaran dari pada mengikuti proses belajar mengajar. Hal ini dikarenakan peserta didik tidak tertarik dan bosan ketika mengikuti proses pembelajaran. Hal inilah yang menyebabkan rendahnya keaktifan peserta didik. Rendahnya keaktifan inilah yang kemudian dikhawatirkan akan berdampak pada penurunan hasil belajar. Oleh karena itu, harus ada perbaikan pembelajaran agar tujuan pembelajaran dapat tercapai. Upaya untuk meningkatkan keaktifan dapat dilakukan melalui beberapa hal, diantaranya dengan menggunakan model pembelajaran. Terdapat berbagai macam model pembelajaran, salah satunya adalah model pembelajaran problem based learning.

Dalam model ini peserta didik dituntut untuk berpikir kritis dalam memecahkan masalah yang ada di dunia nyata atau di sekitar peserta didik. Selain itu, model ini juga mengajarkan peserta didik untuk bekerja sama dalam kelompok sehingga akan menumbuhkan keaktifan dalam pembelajaran dan akan mudah diingat oleh peserta didik karena peserta didik akan memahami dan mencoba masalah yang ada oleh dirinya sendiri. Penerapan model pembelajaran problem based learning pada kompetensi sistem bahan bakar dirasa tepat, karena pada model pembelajaran ini menggunakan masalah yang nyata sebagai bahan pembelajaran. Peserta didik akan memecahkan masalah tersebut secara individu atau kelompok sehingga diharapkan dapat meningkatkan keaktifan belajar. Dengan meningkatnya keaktifan memungkinkan memberikan dampak positif pada keberhasilan belajar (Wardan, 2014)

Berdasarkan uraian permasalahan tersebut, maka dapat diketahui bahwa hasil belajar peserta didik masih rendah diduga karena rendahnya keaktifan peserta didik. Oleh karena itu, perlu adanya perbaikan agar keaktifan dan hasil belajar dapat meningkat. Salah satu upaya untuk meningkatkan keaktifan dan hasil belajar peserta didik adalah dengan menerapkan model pembelajaran problem based learning. Dengan demikian, maka penelitian ini berjudul "Penerapan Model Pembelajaran Problem Based Learning untuk Meningkatkan Keaktifan dan Hasil Belajar Peserta Didik pada Kompetensi Sistem Bahan Bakar Bensin Konvensional Kelas XI TKRA SMK Nasional Berbah”.

\section{METODE}


Jenis penelitian yang akan digunakan adalah Penelitian Tindakan Kelas (PTK). Menurut Supardi (dalam buku Ningrum 2014:35) mengemukakan tujuan penelitian tindakan kelas, diantaranya adalah:

a. Memperhatikan dan meningkatkan kualitas isi, masukan, proses dan hasil pembelajaran

b. Menumbuhkembangkan budaya meneliti bagi tenaga kependidikan agar lebih proaktif mencari solusi akan permasalahan pembelajaran.

c. Menumbuhkan dan meningkatkan produktivitas meneliti para tenaga pendidik dan kependidikan, khususnya mencari solusi masalah-masalah pembelajaran.

d. Meningkatkan kolaborasi antar tenaga pendidik dan tenaga kependidikan dalam memecahkan masalah pembelajaran.

Penelitian ini dilakukan untuk mengatasimasalah pembelajaran yang terdapat didalam kelas agar kualitas belajar peserta didik menjadi lebih baik. Kegiatan dilaksanakan pada satu kelas secara partisipatif dan kolaboratif, artinya peneliti dan guru pengampu akan terlibat langsung untuk berkolaborasi dalam melaksanakan penelitian. Peran peneliti adalah sebagai perancang dan pelaksana dalam proses pembelajaran, sedangkan guru atau mahapeserta didik adalah sebagai kolaborator sekaligus observer pada saat pembelajaran berlangsung.

Penelitian tindakan kelas ini dilakukan di SMK Nasional Berbah yang beralamat di Jalan Tanjungtiro Kalitirto Berbah Sleman Yogyakarta. Pelaksanaan penelitian ini dilakukan pada bulan April-Mei 2019. Penentuan waktu mengacu pada kalender akademik sekolah dan sesuai dengan jadwal mata pelajaran Pemeliharaan Mesin Kendaran Ringan pada kompetensi memahami sistem bahan bakar bensin di SMK Nasional Berbah. Subjek dalam penelitian ini adalah peserta didik kelas XI TKRA SMK Nasional Berbah yang sedang melaksanakan kegiatan pembelajaran pada semester dua tahun ajaran 2018/2019 yang berjumlah 32 peserta didik. Alasan memilih subjek penelitian pada kelas XI TKRA adalah karena kelas tersebut memiliki permasalahan pada keaktifan belajar saat pembelajaran berlangsung dan hasil belajar peserta didik masih banyak yang belum mencapai KKM pada mata pelajaran PMKR. Penelitian ini dibantu oleh guru pengampu mata pelajaran PMKR untuk mengkoordinasikan peserta didik dalam hal pelaksanaan penelitian di kelas XI TKRA SMK Nasional Berbah.

Dalam mengumpulkan data, penelitian ini menggunakan beberapa teknik diantaranya adalah:

a. Observasi

Observasi dalam penelitian ini diartikan sebagai pengamatan yang dilakukan secara 
54 Sukirman, Moch Solikin, Lilik Chaerul Yuswono

langsung dengan melibatkan seluruh indera untuk mendapatkan data keaktifan belajar. Observasi dilakukan dengan cara melihat atau mengamati perilaku peserta didik dan guru pada saat pembelajaran berlangsung, kemudian mencatatnya dalam lembar observasi. Pengumpulan data observasi akan dilakukan oleh seorang observer akan mengamati jalannya pembelajaran yang sedang berlangsung dan mencatatnya dalam lembar observasi.

b. Tes hasil belajar

Teknik ini dilakukan untuk mengukur peningkatan hasil belajar peserta didik dengan memberikan soal evaluasi terkait materi yang diajarkan. Tes ini dilakukan pada setiap akhir siklus atau setelah peserta didik mendapat tindakan dengan menggunakan model problem based learning. Hasil tes tiap siklus ini akan dibandingkan dan didapatkan peningkatan hasil belajar yang diyakini meningkat karena adanya tindakan dengan menerapkan model problem based learning.

c. Dokumentasi

Teknik ini dilakukan untuk mendapatkan data berupa nilai ulangan yang terdahulu, daftar peserta didik, dan RPP guna mendukung dan menguatkan data observasi. Dokumentasi dapat digunakan sebagai arsip yang berisi foto mengenai aktivitas belajar peserta didik selama mengikuti pembelajaran, karena dengan adanya foto maka hasil penelitian akan semakin dapat dipercaya.

Dalam menganalisis data pada penelitian tindakan kelas ini digunakan dua teknik analisis, yaitu:

\section{Analisis data keaktifan belajar}

Analisis ini digunakan untuk mengukur perkembangan keaktifan belajar peserta didik dalam mengikuti proses pembelajaran yang menggunakan model problem based learning. Analisis dilakukan pada lembar observasi dengan menggunakan rumus yang dinyatakan melalui presentase. Aktivitas yang dianalisis pada penelitian ini adalah aktivitas positif dan aktivitas negatif. Rumus yang digunakan untuk menghitung presentase keaktifan belajar peserta didik adalah sebagai berikut:

$$
\begin{aligned}
& P k p(\%)=\frac{\sum \text { siswasetiapindikator positif }}{\sum \text { siswa }} \times 100 \% \\
& P k n(\%)=\frac{\sum \text { siswa setiapindikator negatif }}{\sum \text { siswa }} \times 100 \%
\end{aligned}
$$

Untuk mengukur perkembangan keaktifan positif dan keaktifan negatif, maka dilakukan perbandingan dengan menggunakan rumus sebagai berikut: 


$$
\begin{aligned}
& R k p(\%)=\frac{\text { Epresentase keaktifar posit if }}{\text { Lindibntor pnaitif }} \\
& R k n(\%)=\frac{\text { Epresentase keaktifar negatif }}{\text { ¿indikator negatif }}
\end{aligned}
$$

Dari data hasil perhitungan tersebut kemudian dibandingkan setiap siklusnya. Sehingga dapat diperoleh perkembangan keaktifan belajar yang dilakukan oleh peserta didik selama mengikuti pembelajaran.

Acuan presentase aktivitas positif peserta didik menurut Suharsimi (dikutip oleh Erniwati 2015:5) adalah sebagai berikut.

Tabel 1. Kriteria Aktvitas Positif Peserta Didik

\begin{tabular}{|l|l|}
\hline Tingkat Presentase & Keterangan \\
\hline $76 \%-100 \%$ & Baik Sekali (BS) \\
\hline $51 \%-75 \%$ & Baik (B) \\
\hline $26 \%-50 \%$ & Sedang (S) \\
\hline $1 \%-25 \%$ & Kurang (K) \\
\hline
\end{tabular}

Sedangkan acuan aktivitas negatif peserta didik menurut Slameto (dikutip oleh Erniwati 2015:6) adalah sebagai berikut.

Tabel 2. Kriteria Aktivitas Negatif Peserta Didik

\begin{tabular}{|l|l|}
\hline Tingkat Presentase & Keterangan \\
\hline $0 \%$ & Baik (B) \\
\hline $1 \%-10 \%$ & Cukup Baik (CB) \\
\hline $11 \%-25 \%$ & Cukup (C) \\
\hline $26 \%-49 \%$ & Kurang (K) \\
\hline $50 \%-100 \%$ & Kurang Sekali (KS) \\
\hline
\end{tabular}

2. Analisis data hasil belajar

Analisis ini digunakan untuk mengukur perkembangan hasil belajar peserta didik digunakan teknik analisis data kuantitatif. Analisis ini dilakukan melalui tes hasil belajar yang didapatkan dari setiap akhir siklus. Skor hasil belajar yang diberikan peserta didik berdasarkan perolehan jawaban yang benar dengan skala angka skor antara 0 sampai dengan 100. Untuk menghitung nilai masing-masing peserta didik menggunakan rumus sebagai berikut: Nilai = 
56 Sukirman, Moch Solikin, Lilik Chaerul Yuswono

jumlah skor X 4 Untuk mengetahui perkembangan hasil belajar peserta didik, maka dilakukan perbandingan rata-rata kelas setiap siklusnya. Dari setiap siklus akan dihitung rata-rata kelas dengan menggunakan rumus:

$$
\dot{\mathrm{x}}=\frac{\sum X}{\sum N}
$$

Keterangan :

$\mathrm{X}=$ nilai rata-rata

$\sum \mathrm{X}=$ jumlah semua nilai peserta didik

$\sum \mathrm{N}=$ jumlah peserta didik

Mulyasa (2009:218) menyatakan bahwa hasil pembelajaran dikatakan berhasil apabila terjadi perubahan perubahan perilaku yang bersifat positif pada diri peserta didik seluruhnya atau setidaknya sebagian besar (75\%). Maka dari itu, pembelajaran dapat dikatakan berhasil apabila $\geq 75 \%$ peserta didik mampu mencapai batas Kriteria Ketuntasan Minimun (KKM). Untuk menghitung perkembangan jumlah peserta didik yang mampu mencapai KKM, maka dilakukan perbandingan presentase ketuntasan KKM pada setiap siklusnya. Dari setiap siklus akan dihitung menggunakan rumus sebagai berikut.

$$
P=\frac{\sum n i}{\sum n o} \times 100 \%
$$

Keterangan :

$\mathrm{P}=$ presentase ketuntasan peserta didik

$\sum \mathrm{ni}=$ jumlah peserta didik yang mencapai KKM

$\sum$ no $=$ jumlah seluruh peserta didik

(Sudjana, 2016:109)

\section{HASIL DAN PEMBAHASAN}

\section{Keaktifan belajar peserta didik}

Berdasarkan hasil pengamatan keaktifan belajar peserta didik yang telah dilakukan, dapat diketahui bahwa terjadi peningkatan pada aktivitas positif dan penurunan pada aktivitas negatif. Pada siklus I menunjukkan bahwa ratarata presentase aktivitas positif peserta didik sebesar 51\% dan aktivitas negatif peserta didik sebesar 22\%. Hal ini menunjukkan bahwa aktivitas positif dan negatif peserta didik belum memenuhi kriteria keberhasilan yang telah ditentukan. 
Kemudian penelitian berlanjut pada siklus II yang menunjukkan bahwa rata-rata presentase aktivitas positif peserta didik sebesar $76 \%$ dan aktivitas negatif peserta didik sebesar $14 \%$. Pada siklus II terjadi peningkatan pada aktivitas positif peserta didik sebesar 25\%. Sedangkan aktivitas negatif peserta didik terjadi penurunan dibandingkan pada siklus I yaitu sebesar $8 \%$, sehingga aktivitas negatif pada siklus II sudah memenuhi kriteria keberhasilan yang telah ditentukan. Peningkatan aktivitas positif dan penurunan aktivitas negatif peserta didik sudah memenuhi kriteria keberhasilan yang telah ditentukan. Berikut ini adalah grafik peningkatan keaktifan peserta didik pada siklus I dan siklus II.

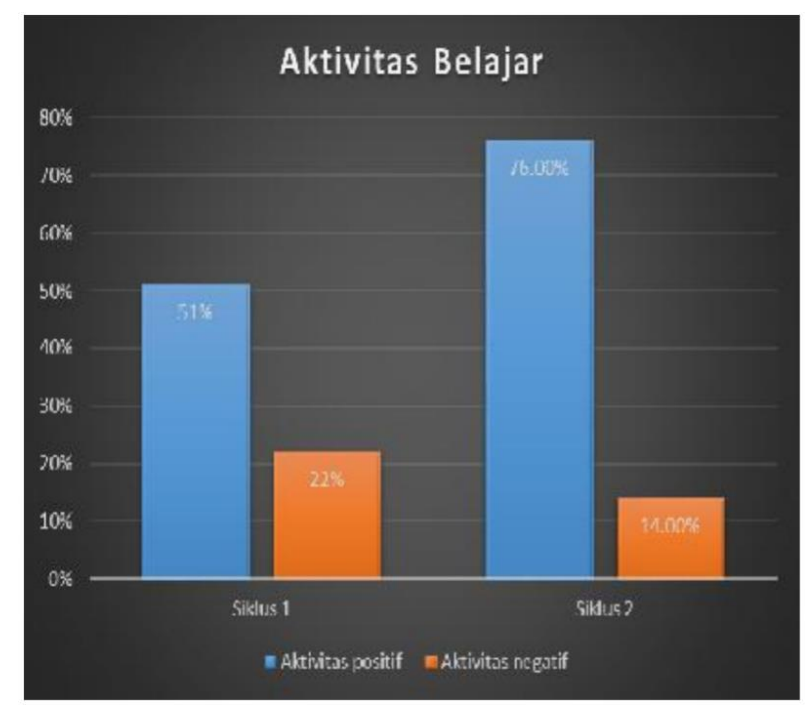

Gambar 1. Grafik Aktivitas Belajar

Berdasarkan grafik aktivitas belajar peserta didik diatas menunjukkan bahwa terjadi peningkatan aktivitas positif peserta didik dari setiap siklusnya. Pada siklus I aktivitas positif peserta didik sebesar $51 \%$, kemudian meningkat pada siklus II menjadi $76 \%$. Sedangkan aktivitas negatif pada siklus I sebesar 22\%, kemudian menurun pada siklus II menjadi 14\%. Dengan demikian dapat diketahui bahwa penerapan model pembelajaran problem based learning pada kompetensi sistem bahan bakar bensin Konvensional kelas XI TKRA SMK Nasional Berbah dapat meningkatkan keaktifan belajar peserta didik. Peningkatan keaktifan belajar peserta didik terjadi pada setiap siklusnya yang membuktikan bahwa penerapan model pembelajaran problem based learning dapat digunakan sebagai alternatif variasi model pembelajaran untuk mendorong peserta didik berperan aktif dalam pembelajaran.

\section{Hasil Belajar}

peserta didik Penerapan model pembelajaran problem based learning juga dapat meningkatkan hasil belajar peserta didik. Hal ini dapat dilihat dari nilai rata-rata kelas dan ketuntasan peserta didik yang mengalami peningkatan di setiap siklusnya. 


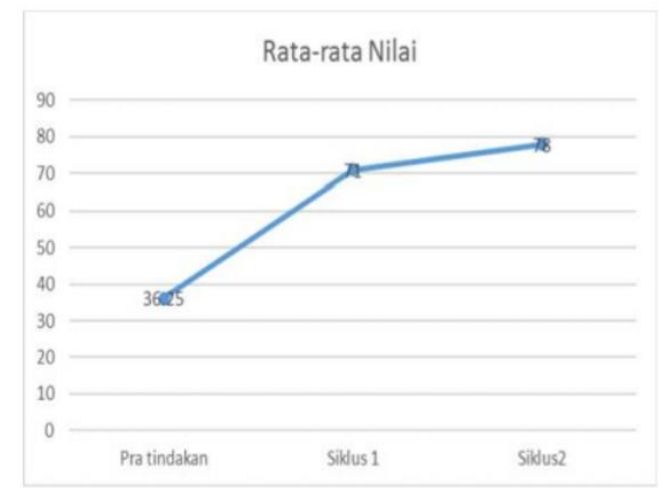

Gambar 2. Grafik Nilai Rata-rata Kelas

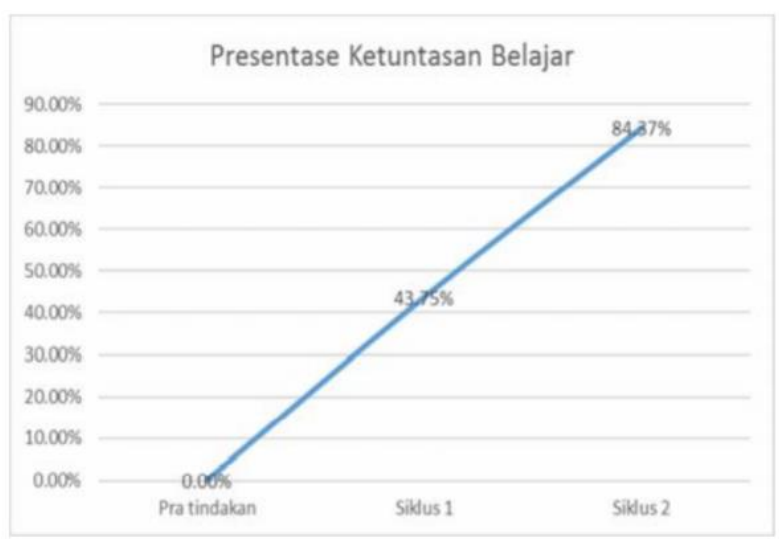

Gambar 3. Grafik Ketuntasan Belajar Peserta Didik

Berdasarkan pada kedua grafik diatas dapat diketahui bahwa terjadinya peningkatan nilai ratarata kelas dan presentase ketuntasan belajar peserta didik. Data pra tindakan menujukan bahwa nilai rata-rata kelas sebesar 36,25 dan presentase ketuntasan kelas sebesar 0\%. Dengan data ini dapat diketahui bahwa pada pra tindakan nilai rata-rata kelas dan ketuntasan kelas dapat dikatakan rendah karena belum mencapai KKM. Pada siklus I diketahui rata-rata kelas meningkat menjadi 71 dan presentase ketuntasan menjadi 43,75\%. Akan tetapi hasil siklus I ini masih belum mampu mencapai KKM, sehingga berlanjut pada siklus II. pada siklus II rata-rata kelas meningkat lagi menjadi 78 dan presentase ketuntasan menjadi 84,37\%. Hasil pada siklus II menunjukkan bahwa rata-rata kelas dan ketuntasan peserta didik sudah mencapai KKM dan kriteria keberhasilan yang telah ditentukan. Peningkatan nilai rata-rata kelas dari pra tindakan ke siklus I sebesar 34,75 kemudian dari siklus I ke siklus II sebesar 7. Ketuntasan kelas juga terjadi peningkatan pada setiap siklusnya dari pra tindakan ke siklus I sebesar 3,75\%. Kemudain dari siklus I ke siklus II meningkat lagi dengan selisih sebesar 40,62\%. Peningkatan nilai ratarata kelas dan ketuntasan peserta didik yang terjadi pada setiap siklusnya menunjukkan bahwa penerapan model pembelajaran problem based learning dapat meningkatkan hasil belajar peserta didik kelas XI TKRA pada kompetensi memahami sistem bahan bakar bensin 
konvensional. Dengan demikian dapat diketahui bahwa model pembelajaran problem based learning dapat dijadikan alternatif model pembelajaran untuk meningkatkan hasil belajar peserta didik.

\section{SIMPULAN}

Berdasarkan dari data dan pembahasan diketahui bahwa dengan menerapkan model pembelajaran model PBL dapat meningkatkan keaktifan dan hasil belajar peserta didik.

Guru dapat menerapkan model pembelajaran problem based learning pada mata pelajaran atau kompetensi lain yang diharapkan dapat meningkatkan keaktifan maupun hasil belajar peserta didik. Selain itu, guru dapat juga mengembangkan model pembelajaran problem based learning agar tercipta proses pembelajaran yang aktif dan berpusat pada peserta didik sehingga dapat meningkatkan keaktifan maupun pemahaman peserta didik terhadap materi yang diajarkan.

\section{DAFTAR PUSTAKA}

Anonim. (2017). Tingkat Pengangguran terbuka. Diakses pada hari jumát tanggal 11 Februari 2019 pukul 13.20 WIB. from https://www.bps.go.id/pressrelease/2017/11/06/1 377/agustus-2017-tingkatpengangguranterbuka--tpt--sebesar-5-50-persen.html

Mulyasa. (2009). Implementasi Kurikulum Tingkat Satuan Pendidikan. Jakarta: PT Bumi Aksara.

Ningrum, Epon. (2014). Penelitian Tindakan Kelas: Panduan Praktis dan Contoh. Yogyakarta: Ombak.

Sudjana, Nana. (2016). Penilaian Proses Hasil Belajar Mengajar. Bandung: Remaja Rosdakarya Offset.

Sofyan. H., \& Komariah. K. (2016). Pembelajaran problem based learning dalam implementasi kurikulum 2013 di SMK. UNY: Jurnal Pendidikan Vokasi,

Nafiah., Y., \& Suyanto., W. (2014). Penerapan Model Problem-Based Learning Untuk Meningkatkan Keterampilan Berpikir Kritis Dan Hasil Belajar Siswa. UNY: Jurnal Pendidikan Vokasi 
60 Sukirman, Moch Solikin, Lilik Chaerul Yuswono 